\title{
Challenges encountered in employing a low tidal volume ventilation strategy in patients at risk of ARDS
}

\author{
R Fisher, , A Selman, Z Brummell, BO Rose \\ From ESICM LIVES 2015 \\ Berlin, Germany. 3-7 October 2015
}

\section{Introduction}

Ventilator strategies that use tidal volumes (TVs) limited to $6 \mathrm{ml} / \mathrm{kg}$ IBW (ideal body weight) have been shown to reduce mortality in patients with ARDS (acute respiratory distress syndrome). [1] It is suggested that using these same low tidal volumes in other critically ill patients may reduce the progression to ARDS. [2,3] An initial audit in the ICU at University Hospital Lewisham demonstrated that patients without ARDS were receiving mandatory ventilation in excess of $8 \mathrm{ml} / \mathrm{kg} \mathrm{IBW}$ $>40 \%$ of the time.

\section{Objectives}

To assess the effectiveness of a new protocol and education program in reducing rates of excessive TV ventilation in a general ICU.

\section{Methods}

Data was collected on all ventilated patients without ARDS during three 21-day periods: an initial audit (Febuary 2013); a re-audit following the initiation of the protocol and education program (June 2013); a subsequent reaudit following redrafting of the protocol and introduction of PRVC (Pressure Regulated Volume Control) as the default mode of mandatory ventilation (November 2013).

Mode of ventilation and measured TV were recorded hourly by the patient's bedside nurse. Investigators estimated IBW by using the patient's ulna length as a surrogate of height.

\section{Results}

During the initial audit period 17 patients received a total of 1393 hours of mandatory ventilation, of which

University Hospital Lewisham, Critical Care Unit, London, United Kingdom
$40.4 \%$ of TVs were $>8 \mathrm{ml} / \mathrm{kg} \mathrm{IBW}$. More than half of the patients studied received TVs $>8 \mathrm{ml} / \mathrm{kg} \mathrm{IBW}$ for the majority of the study period.

During the first re-audit period 16 patients received a total of 794 hours of mandatory ventilation, of which $40.4 \%$ was $>8 \mathrm{ml} / \mathrm{kg} \mathrm{IBW}(\mathrm{p}=1)$.

During the second re-audit period 15 patients received a total of 846 hours of mandatory ventilation, of which $33.4 \%$ was $>8 \mathrm{ml} / \mathrm{kg} \mathrm{IBW}(\mathrm{p}=0.001$ ) (Figure 1$)$.

\section{Conclusions}

Introduction of a formalised protocol supported by an education program failed to decrease the rate of excessive TV ventilation in ICU patients without ARDS. The addition to the protocol of a default mode of ventilation that requires staff to set the target TV significantly reduced rates of excessive ventilation, however TVs $>8 \mathrm{ml} / \mathrm{kg}$

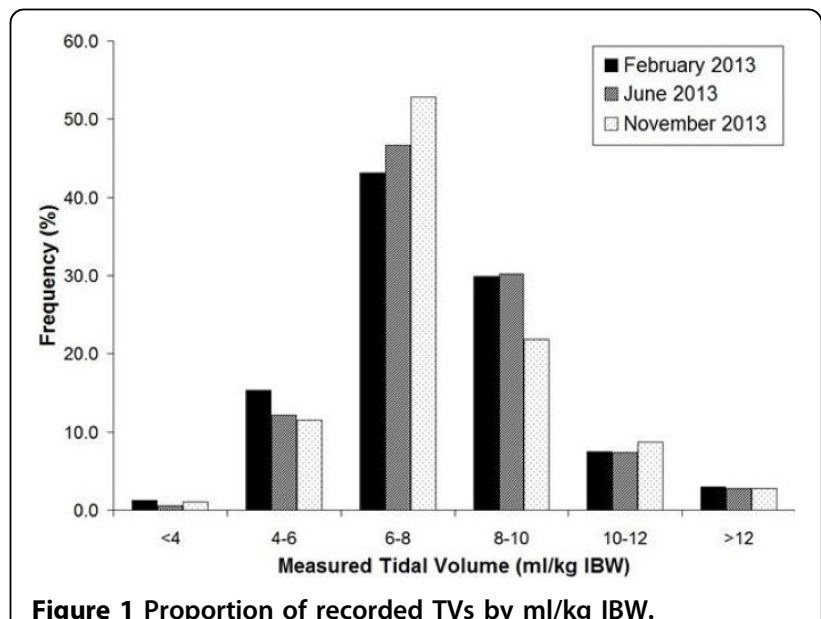

Figure 1 Proportion of recorded TVs by $\mathrm{ml} / \mathrm{kg}$ IBW.

(c) 2015 Fisher et al.; This is an Open Access article distributed under the terms of the Creative Commons Attribution License (http:// creativecommons.org/licenses/by/4.0), which permits unrestricted use, distribution, and reproduction in any medium, provided the original work is properly cited. 
IBW continued to be delivered a third of the time and there remains scope for improvement. These results highlight the difficulty in changing staff practice (both medical and nursing) in the ICU.

Published: 1 October 2015

\section{References}

1. The Acute Respiratory Distress Syndrome Network. Ventilation with lower tidal volumes as compared with traditional tidal volumes for acute lung injury and the acute respiratory distress syndrome. NEJM 2000, 342:1301-1308.

2. Determann, et al: Ventilation with lower tidal volumes as compared with conventional tidal volumes for patients without acute lung injury: a preventive randomised controlled trial. Critical Care 2010, 14(1):R1.

3. Fuller, et al: Lower tidal volume at initiation of mechanical ventilation may reduce progression to acute respiratory distress syndrome: a systematic review. Critical Care 2013, 17:R11.

doi:10.1186/2197-425X-3-S1-A270

Cite this article as: Fisher et al: Challenges encountered in employing a low tidal volume ventilation strategy in patients at risk of ARDS.

Intensive Care Medicine Experimental 2015 3(Suppl 1):A270.

\section{Submit your manuscript to a SpringerOpen ${ }^{\odot}$ journal and benefit from:}

- Convenient online submission

- Rigorous peer review

- Immediate publication on acceptance

- Open access: articles freely available online

- High visibility within the field

- Retaining the copyright to your article 